\title{
Ethnomedicinal Plants Used in Balasore District of Odisha: A Comprehensive Report
}

\section{Sushree Sangita Mohapatra ${ }^{1}$, Jadav Sarma ${ }^{1}$, Rohini Kumar Roy ${ }^{1}$, Sumitra Panigrahi ${ }^{2}$ and Subha Ganguly ${ }^{3 *}$}

\author{
${ }^{1}$ Department of Pharmacology and Toxicology, College of Veterinary Science, \\ Khanapara, Assam Agricultural University, Guwahati, Assam, India \\ ${ }^{2}$ Department of Veterinary Public Health and Epidemiology, Lala Lajpat Rai University of \\ Veterinary and Animal Sciences, Hisar, Haryana, India \\ ${ }^{3}$ Department of Veterinary Microbiology, Arawali Veterinary College (Affiliated to Rajasthan \\ University of Veterinary and Animal Sciences, Bikaner), N.H. - 52 Jaipur Road, Bajor, Dist. \\ Sikar, Rajasthan, India \\ *Corresponding author
}

\section{A B S T R A C T}

Keywords

Balasore, Medicinal plants

Article Info

Accepted:

14 December 2017

Available Online:

10 January 2018
A Survey was conducted with a structured schedule to gather information on traditionally used medicinal plants of Balasore district of Odisha. In addition, some interviews were also conducted with village headman and villagers to gather information. The information gathered was recorded for further studies. Twenty six different indigenous medicinal plant species are being used by rural people. Among them Ananas comosus (deworming), Barleria prionitis (wounds), Psidium guajava leaves and fruit (diarrhea), Nyctanthes arbor leaves (fever), Lawsonia inermis (Jaundice) etc. are used by the villagers for the cure.

\section{Introduction}

From the time immemorial to the present, herbal medicines have been proved their importance in curing various diseases.

Statistics says that the majority of the population (roughly $80 \%$ ) of Asia and South and Central America, still use herbal medicine for their primary healthcare (Kamboj, 2000;
Owoabi et al., 2007). It is found that there are many drugs that are prescribed worldwide are of plant origin (Harvey, 1999; Rates, 2001).

Balasore is one of the coastal Districts of Odisha. It lies on the northernmost part of the state. The District is located at $21^{\circ} 3^{\prime}$ to $21^{\circ}$ $59^{\prime}$ north latitude and $86^{\circ} 20^{\prime}$ to $87^{\circ} 29^{\prime}$ East Longitude. The Balasore district is one of the ethnically blessed district of Odisha. 
Table.1 Representation of various herbal medicines used in Balasore district of Odisha

\begin{tabular}{|c|c|c|c|c|c|}
\hline Disease & Plant used & Scientific name & Common name & Parts used & Procedure of using \\
\hline \multirow[t]{2}{*}{ 1. EAR PAIN } & Lemon & Citrus limon & LEMBU & FRUIT & $\begin{array}{l}\text { Lemon juice is heated and put in the ear drop by drop for } \\
4-5 \text { drops }\end{array}$ \\
\hline & Black tulsi & Ocimum tenuiflorum & KALA TULASI & LEAVES & Leaves are crushed and $4-5$ drops are poured in the ear. \\
\hline \multirow[b]{2}{*}{ 2. COUGH } & Tulsi & Ocimum sanctum & TULASI & LEAVES & \multirow{2}{*}{$\begin{array}{l}\text { Equal amount of Tulsi leaves, long pepper and honey is } \\
\text { mixed and taken orally. }\end{array}$} \\
\hline & Long pepper & Piper longum & LABANG & FRUIT & \\
\hline \multirow[t]{2}{*}{ 3. JAUNDICE } & Henna & Lawsonia inermis & MANJUATI & $\begin{array}{l}\text { LEAF, } \\
\text { BARK, } \\
\text { ROOTS }\end{array}$ & Leaf paste/bark decoction/Root paste is taken orally \\
\hline & Abutilon & Abutilon indicum & PEDI PEDICA & ROOT & Root paste taken orally \\
\hline $\begin{array}{l}\text { 4.THROAT } \\
\text { CANCER }\end{array}$ & Ginger & Zingiber officinale & ADA & RHIZOME & $\begin{array}{l}\text { Dried ginger is mixed with sugar and honey and taken } \\
\text { orally } 3 \text { times a day }\end{array}$ \\
\hline 5. FEVER & Night jasmine & Nyctanthes arbor & GANGASIULI & LEAF & $\begin{array}{l}\text { 4-5 leaves are taken and grinded and the juice is } \\
\text { extracted. The juice is mixed with one teaspoon full of } \\
\text { honey and taken orally. }\end{array}$ \\
\hline 6. COMMON COLD & Tulsi & Ocimum sanctum & TULASI & LEAF & 5-6 leaves are taken with one spoon of honey \\
\hline 7.DEWORMING & Pineapple & Ananas comosus & $\begin{array}{l}\text { ANARAS/ } \\
\text { SAPURI }\end{array}$ & LEAF & Leaves are crushed and the juice is taken orally \\
\hline \multirow[t]{7}{*}{ 8. DIARRHOEA } & Dalimba & Punica granatum & DALIMBA & $\begin{array}{l}\text { LEAVES, } \\
\text { FRUIT }\end{array}$ & Leaves/fruit are crushed and take orally \\
\hline & Guava & Psidium guajava & PIJULI & $\begin{array}{l}\text { LEAF, } \\
\text { FRUIT }\end{array}$ & Paste of Leaves or fruits are taken orally \\
\hline & Tamarind & Tamarindus indica & TENTULI & BARK & Decoction is made out of bark and taken orally \\
\hline & Basang & Adhatoda vasica & BASANGA & LEAF & Leaves are grinded and the juice is taken orally \\
\hline & Bel & Aegle marmelos & BELA & LEAF & 3-4 leaves are taken orally \\
\hline & Onion & Allium cepa & PIAJA & $\begin{array}{l}\text { ROOT, } \\
\text { TUBER }\end{array}$ & Taken orally \\
\hline & Brinjal & Solanum melogena & BAIGANA & FRUIT & $\begin{array}{l}\text { Goat's gall bladder is taken and inserted inside the } \\
\text { roasted Brinjal and taken orally. }\end{array}$ \\
\hline $\begin{array}{l}\text { 9.NIGHT } \\
\text { BLINDNESS }\end{array}$ & Elephant foot & $\begin{array}{l}\text { Amorphophallus } \\
\text { paeoniifolius }\end{array}$ & OLUA & ROOT & Roasted elephant foot is taken with salt and mustard oil. \\
\hline \multirow{3}{*}{ 10. PILES } & Bel & Aegle marmelos & BELA & LEAVES & $\begin{array}{l}\text { Leaves are taken and crushed to extract juice and taken } \\
\text { orally }\end{array}$ \\
\hline & $\begin{array}{l}\text { Indian gingseng/poison } \\
\text { gooseberry }\end{array}$ & Withania somnifera & ASWAGANDHA & BARK & Decoction is made and taken orally \\
\hline & Pudina & Mentha arvensis & PODINA & LEAF & $\begin{array}{l}\text { 5-6 Pudina leaves are mixed with } 1 \text { gram of ginger and } \\
\text { salt and taken orally }\end{array}$ \\
\hline
\end{tabular}


Int.J.Curr.Microbiol.App.Sci (2018) 7(1): 1959-1963

\begin{tabular}{|c|c|c|c|c|c|}
\hline \multirow[t]{2}{*}{ 11. ANOREXIA } & Ginger & Zingiber officinale & ADA & ROOT & \multirow[b]{2}{*}{ Smell crushed onion } \\
\hline & Onion & Allium сера & PIAJA & ROOT & \\
\hline \multirow[t]{2}{*}{ 12. INSOMNIA } & Sushni leaves & Marsilea quadrifolia & SUNSUNIA & LEAF & Cooked leaves is taken \\
\hline & Callotropis & Callotropis & ARAKHA & MILK & $\begin{array}{l}5-6 \text { drops of milk of plant is put in the thumb toe } \\
\text { opposite to the eye affected. }\end{array}$ \\
\hline $\begin{array}{l}13 . \\
\text { CONJUCTIVITIS }\end{array}$ & Pudina/Mentha/Mint & Mentha spp. & PODINA & LEAF & $\begin{array}{l}\text { Pudina leaves are mixed with black pepper and to be } \\
\text { taken with water }\end{array}$ \\
\hline \multirow[t]{2}{*}{ 14. ACIDITY } & Black Pepper & Piper nigrum & GOLA MARICHA & $\begin{array}{l}\text { DRIED } \\
\text { FRUIT }\end{array}$ & \multirow[t]{2}{*}{ Root paste is used applied to the joints } \\
\hline & Rosary pea/crab's eye & Abrus precatorius & RATI & ROOTS & \\
\hline \multirow[b]{3}{*}{ 15. RHEUMATISM } & Basang & Adhatoda vasica & BASANGA & LEAF & Crushed leaves are taken and applied to the joints \\
\hline & Castor & Ricinus communis & JADA & SEED OIL & Seed oil used in the area of pain \\
\hline & Basang & Adhatoda vasica & BASANGA & LEAF & Leaf paste is used \\
\hline \multirow[b]{4}{*}{ 16. MALARIA } & $\begin{array}{l}\text { Beggar weed/ angel hair/ } \\
\text { love vine }\end{array}$ & Cuscuta reflexa & NIRMULI & STEM & Paste of stem is taken orally \\
\hline & Java grass & Cyperus rotundus & MUTHA & ROOT & Root paste is used \\
\hline & False daisy/bhringraj & Eclipta alba & BHURUSUNGA & LEAF & Leaf paste is taken orally \\
\hline & Night jasmine & Nyctanthes arbor & GANGASIULI & LEAF & $\begin{array}{l}\text { 4-5 leaves are taken and grinded and the juice is } \\
\text { extracted. The juice is mixed with one teaspoon full of } \\
\text { honey and taken orally. }\end{array}$ \\
\hline 17. HEADACHAE & Coat buttons/ sanjeevani & Tridax procubens & $\begin{array}{l}\text { BISHALYAKARA } \\
\text { NI }\end{array}$ & LEAF & $\begin{array}{l}\text { Crushed and applied on the wounds and cuts } \\
\text { superficially }\end{array}$ \\
\hline \multirow{3}{*}{$\begin{array}{ll}\text { 18.CUTS } & \text { AND } \\
\text { WOUNDS } & \\
\end{array}$} & Black myrobalan & Terminalia chebula & $\begin{array}{l}\text { KASA } \\
\text { PHALA/HARIDA }\end{array}$ & $\begin{array}{l}\text { FRUIT, } \\
\text { BARK }\end{array}$ & Fruit paste and bark decoction is applied on the wound \\
\hline & Percupine flower & Barleria prionitis & DASKARENTA & LEAF & Crushed and applied on the wound and cut \\
\hline & Papaya & Carica papaya & AMRITA VANDA & FRUIT & Crushed to make juice and taken orally \\
\hline \multirow[t]{2}{*}{ 19. TOOTHACHAE } & Guava & Psidium guajava & PIJULI & BARK & $\begin{array}{l}\text { Decoction is made by taking } 100 \text { grams of bark, boiled } \\
\text { in } 500 \mathrm{ml} \text { water. The water has to be boiled till it } \\
\text { becomes } 125 \mathrm{ml} \text {. Then the decoction is used to gargle for } \\
2-3 \text { times a day. }\end{array}$ \\
\hline & $\begin{array}{l}\text { Bullet wood/ spanish } \\
\text { cherry }\end{array}$ & Mimusops elengi & BAULA & BARK & $\begin{array}{l}\text { Decoction is made by taking } 100 \text { grams of bark, boiled } \\
\text { in } 500 \mathrm{ml} \text { water. The water has to be boiled till it } \\
\text { becomes } 125 \mathrm{ml} \text {. Then the decoction is used to gargle for } \\
2-3 \text { times a day. }\end{array}$ \\
\hline $\begin{array}{l}\text { 20.MEMORY } \\
\text { POWER }\end{array}$ & Brahmi & Bacopa monnieri & BRMHII & $\begin{array}{l}\text { WHOLE } \\
\text { PLANT }\end{array}$ & Crushed to make juice and taken orally \\
\hline
\end{tabular}


Some of the villages of this district are located in the remote areas, with no easy access to the hospitals for treatment of the patient. Therefore traditionally some plants are being used for the treatment.

There are a few works that has been done on herbal plants in the nearby districts (Ganguly, 2013; Ganguly and Verma, 2015; Panda et al., 2016a, b; Wakchaure et al., 2016; Ganguly, 2017).

\section{Materials and Methods}

A Survey was conducted in 2016-2017 with a structured schedule to gather information on traditionally used medicinal plants of the district. In addition, some interviews were conducted with village headman and villagers to gather information. The information gathered was recorded for further studies.

The detailed information regarding local names, parts used, purpose and procedure of use were collected. The collected information was rechecked by comparing the data collected from nearby villages and were also checked with available literatures (Panda et al., 2016a, b).

\section{Results and Discussion}

The findings are presented in the Table 1.

An effort has been made to document various herbal plants and their procedure of use in various diseases in Balasore district. Twenty six different indigenous medicinal plant species are being used by rural people. Among them Ananas comosus (deworming), Barleria prionitis (wounds), Psidium guajava leaves and fruit (diarrhoea), Nyctanthes arbor leaves (fever), Lawsonia inermis (Jaundice), Withania somnifera (Piles), Adhatoda vasica (Rheumatism) etc. are used by the villagers for the cure.
Though the plants are used traditionally, some of these are authenticated by various workers. Others are needed to be authenticated experimentally.

\section{Acknowledgement}

The authors are thankful to headmen of the different villages for providing information related to our work.

\section{References}

Ganguly, S. 2013. A Handbook on Traditional Medicinal Plants, Herbs and Fruits in Indian Agriculture and Forestry. 1st ed., International E-Publication, ISBN 97881-927544-5-1]. Official E-Book (Section: Agriculture and Forestry Sciences). Publication of the International Science Community Association, Indore, UP, India.

Ganguly, S. 2017. Herbal Antioxidant Agents and its Pharmacological and Medicinal Properties. $1^{\text {st }}$ ed., Publisher: Research maGma Group, Solapur (Maharashtra), India. ISBN 978-1-365-90767-8

Ganguly, S. and Verma, D. 2015. A Guide Book on Biological, Pharmaceutical and Chemical Implications of Various Indigenous Plants, Herbs and Fruits in Traditional and Alternative Medicine Practices $\left(1^{\text {st }}\right.$ ed). Book Publication of Society of Education, Agra, India.

Harvey, A.L. 1999. Medicines from nature: are natural products still relevant to drug discovery. Trends. Pharmacol. Sci., 4(20): 196-8.

Kamboj, V.P. 2000. Herbal medicine. Current Science, 78: 35-39.

Owoabi, J.O., Eric, K.I., Obasuyi, O.O. 2007. Antifungal and antibacterial activities of the ethanol and aqueous extract of Kigella Africana (Bignoniaceae) stem bark. African Journal Biotechnology, 6: 1677-80. 
Panda, T., Mishra, N., Pradhan, B.K. 2016a. Folk Knowledge on Medicinal Plants Used for the Treatment of Skin Diseases in Bhadrak District of Odisha, India. Med. Aromat. Plants, 5: pp. 262. doi:10.4172/2167-0412.1000262

Panda, T., Mishra, N., Pradhan, B.K., Mohanty, R. 2016b. Some less known folk medicine in Bhadrak and Kendrapara districts of Odisha, India, Micro Medicine, 4(1): 8-20.

Rates, S.M. 2001. Plants as source of drugs. Toxicon, 39: 603-13.
Wakchaure, R., Ganguly, S. and Praveen, P.K. 2016. Ocimum sanctum (Tulsi), the queen of herbs: A Review. Chap. 12, pp. 166-73. In: Biochemistry and Therapeutic Uses of Medicinal Plants. eds. Prof. Abbas Ali Mahdi, Prof. Y.K. Sharma, Dr. Murtaza Abid (India) and Dr. M.M. Abid Ali Khan (India). Discovery Publishing House Pvt. Ltd., New Delhi, India. Edition: 2017. ISBN 978-93-5056-866-8

\section{How to cite this article:}

Sushree Sangita Mohapatra, Jadav Sarma, Rohini Kumar Roy, Sumitra Panigrahi and Subha Ganguly. 2018. Ethnomedicinal Plants Used in Balasore District of Odisha: A Comprehensive Report. Int.J.Curr.Microbiol.App.Sci. 7(01): 1959-1963. doi: https://doi.org/10.20546/ijcmas.2018.701.237 